Jurnal Ilmu-Ilmu Peternakan 26 (2): 8 - 13

ISSN: 0852-3681

E-ISSN: 2443-0765

CFakultas Peternakan UB, http://jiip.ub.ac.id/

\title{
Pengaruh ekstrak daun kersen terhadap daya tetas dan mortalitas telur itik hibrida
}

\author{
Fatikhatul Huda Alkhakim, Muhammad Ngalaul Huda, Galuh Dianita Fitri, Dewi Am- \\ barwati dan Heli Tistiana
}

Fakultas Peternakan, Universitas Brawijaya, Malang

Jl. Veteran Malang 65145 Jawa Timur

helly_satwa@yahoo.co.id

\begin{abstract}
Duck was one of animal protein resources which still has a low hatchability rate. There were Staphylococcus aureus and Salmonella sp.bacteria on hatch egg that can influence mortality of embryos. The objective of the research was to investigate the potential of Muntingia calabura leaf extract as natural antibacteria on the hatchability and embryos mortality of duck's egg. The research method was field experiment by completely randomized design with five treatments and four replications: P0 (without treatment), A0 (chemical antibacteria), P1(10\% of Muntingia calabura leaf extract), P2 (20\% of Muntingia calabura leaf extract) and P3 (30\% of Muntingia calabura leaf extract). These research used four hundred eggs and semi automatical machine for 28 days. Data were analyzed using one-way Anova. The results showed that Muntingia calabura leaf extract has a very significant effect $(\mathrm{P}<0,01)$ on hatchability and embryos mortality. The best treatment was found on $20 \%$ of Muntingiacalabura leaf extract which increased $12,01 \%$ ofhatchability and decreased $43,42 \%$ of mortality rate.
\end{abstract}

Keywords: Muntingia calabura, antibacteria, hatchability, embryos mortality

\section{PENDAHULUAN}

Ternak itik memiliki peran penting sebagai penyedia protein hewani berupa daging dan telur. Seiring berjalannya waktu kebutuhan masyarakat terhadap daging dan telur itik cenderung meningkat, tetapi tidak diimbangi dengan ketersediaan pasokan produk yang mencukupi. Menurut Direktorat Jendral Peternakan (2010), peran itik sebagai penghasil daging di Indonesia masih rendah, yaitu hanya dapat memenuhi 6,4 ribu ton dari kebutuhan itik sebesar 14,3 ribu ton, sehingga kekurangan daging mencapai 7,9 ribu ton. Hal ini terjadi dikarenakan ketersediaan
Day Old Duck (DOD) sebagai bibit itik sering mengalami kelangkaan.

Permasalahan ini membutuhkan solusi untuk menunjang produksi DOD itik dalam jumlah besar secara massal. Penggunaan mesin tetas sebagai media penetasan telur itik sudah banyak dilakukan, tetapi seringkali daya tetas telur itik rendah dikarenakan rendahnya higienitas telur tetas itik. Salah satu faktor yang harus diperhatikan dalam proses penetasan adalah kebersihan kerabang telur yang merupakan bagian terluar telur yang masih mengandung kotoran terutama eskreta sehingga berpotensi sebagai sumber bakteri pathogen yang mampu mengganggu pertumbuhan em- 
brio. Anderson (2012) menyebutkan bahwa bakteri Staphylococcus aureus dan Salmonella sp. banyak ditemukan pada telur tetas. Kedua bakteri tersebut akan dapat menyebabkan kegagalan penetasan yang disebabkan oleh matinya embrio (Soeripto dan Poeloengan, 1991). Oleh karena itu proses desinfeksi pada telur itik tetas harus dilakukan.

Proses desinfeksi telur tetas biasanya menggunakan formaldehyde atau formalin sebagai desinfektan. Formalin yang digunakan sebagai desinfektan dapat berakibat fatal pada matinya embrio dan meningkatkan abnormalitas ketika dosis penggunaannya berlebihan (Nandhra dkk., 2012). Hal ini diperkuat oleh Zamzamy dkk.(2015) yang menyebutkan bahwa desinfeksi dengan bahan kimia pada konsentrasi rendah tidak dapat membunuh bakteri patogen pada telur, sedangkan pada konsentrasi yang terlalu tinggi dapat membunuh embrio telur. Oleh sebab itu, diperlukan bahan herbal yang mampu menggantikan fungsi formalin sebagai desinfektan. Beberapa bahan herbal yang disinyalir mampu menghambat bahkan membunuh bakteri patogen pada telur yaitu daun kersen.

Daun kersen (Muntingia calabura) memiliki beberapa kandungan senyawa aktif yang mampu bekerja sebagai antibakteri. Flavonoid, saponin dan tanin terkandung dalam daun kersen bersifat antibakteri (Kurniawan dkk., 2013). Flavonoid mampu berperan secara langsung sebagai antibakteri dengan mengganggu fungsi dari bakteri dan tanin. Selain itu, flavonoid dapat menghambat enzim ekstraseluler bakteri dan mengambil alih substrat yang digunakan dalam pertumbuhan bakteri sehingga mampu menghambat pertumbuhannya (Nurwantoro dan Resmisari., 2004). Yudhistira, dkk. (2012) menyatakan bahwa senyawa saponin dapat merusak membran sel mikroba dengan cara me- ningkatkan permeabilitas sel sehingga terjadi perubahan struktur sel dan fungsi membran yang menyebabkan denaturasi protein membran dan membran sel mengalami lisis dan rusak. Penelitian tentang penggunaan daun kersen sering dilakukan. Salah satunya adalah hasil penelitian Prasetyanti, dkk (2016) yang menunjukkan bahwa daun kersen efektif untuk menurunkan jumlah bakteri dalam susu dan skor CMT. Selain itu, daun kersen dapat digunakan sebagai alternatif antiseptik untuk teat dipping sapi perah dan sebagai alternatif untuk pengobatan mastitis sub klinis.

Potensi besar yang dimiliki daun kersen (Muntingia calabura) dengan senyawa antibakteri yang dimiliki membuka peluang untuk dapat digunakan sebagai pengganti formalin dalam proses fumigasi telur tetas. Oleh karena itu, penelitian ini bertujuan untuk mengetahui manfaat ekstrak daun kerses (Muntingia calabura) sebagai desinfektan alami dan pengaruhnya terhadap daya tetas telur itik.

\section{MATERI DAN METODE}

Penetasan telur itik dilaksanakan di kandang penetasan Desa Junrejo, Kabupaten Malang. Ekstraksi daun kersen sebagai antibakteri alami dilaksanakan di Laboratorium Materia Medica, Batu, Malang. Penelitian ini dilaksanakan selama 5 bulan. Materi penelitian adalah 400 butir telur itik Hibrida yang diperoleh dari peternakan rakyat di Desa Junrejo, Kabupaten Malang. Telur tetas yang digunakan telah terseleksi menurut berat telur, bentuk telur, dan warna telur. Aquades dan etanol dibeli dari toko farmasi.

Prosedur pembuatan ekstrak daun kersen dimulai dari daun kersen yang diambil dari Desa Junrejo, Kota Batu dikeringkan dengan cara dianginanginkan selama 2 hari. Setelah itu dilakukan pengovenan pada suhu $40^{\circ} \mathrm{C}$ 
selama 17 jam. Setelah kering, daun kersen digiling (grinding) untuk membentuk serbuk simplisia. Selanjutnya, serbuk simplisia daun kersen mulai diekstraksi. Daun kersen dimaserasi dengan etanol $70 \%$ selama 48 hari. Hasil maserasi disaring dengan kertas saring hingga dihasilkan maserat. Selanjutnya maserat diuapkan agar kadar etanol $70 \%$ menghilang. Setelah itu, maserat kembali dioven dengan suhu $40^{\circ} \mathrm{C}$ selama 12 jam. Setelah ekstrak sudah siap untuk digunakan, kemudian ditakar sesuai perlakuan dan diencerkan dengan aquades.

Penelitian ini menggunakan 4 mesin tetas semi otomatis berkapasitas 100 butir. Setiap mesin tetas dilengkapi 4 lampu 10 watt sebagai pemanas dan termostat pengatur suhu. Mesin tetas tersebut juga dilengkapi termometer indikator suhu dan higrometer indikator kelembaban. Sebelumnya, suhu mesin tetas diatur $38,5^{\circ} \mathrm{C}$ dan dibersihkan dari kotoran sisa penetasan sebelumnya.

Telur itik pada mesin tetas dibalik secara manual 3 kali sehari mulai hari ke-4 dan pembalikan dihentikan pada hari ke-25. Peneropongan telur dilakukan pada hari ke-4, 14 dan 21 untuk mengetahui perkembangan dan mortalitas embrio. Embrio yang mati saat peneropongan langsung dikeluarkan dari mesin untuk meminimalisir exploding egg.

\section{Rancangan penelitian}

Penelitian ini menggunakan rancangan acak lengkap dengan 5 kali perlakuan dan 4 kali ulangan. Perlakuan yang diberikan adalah:

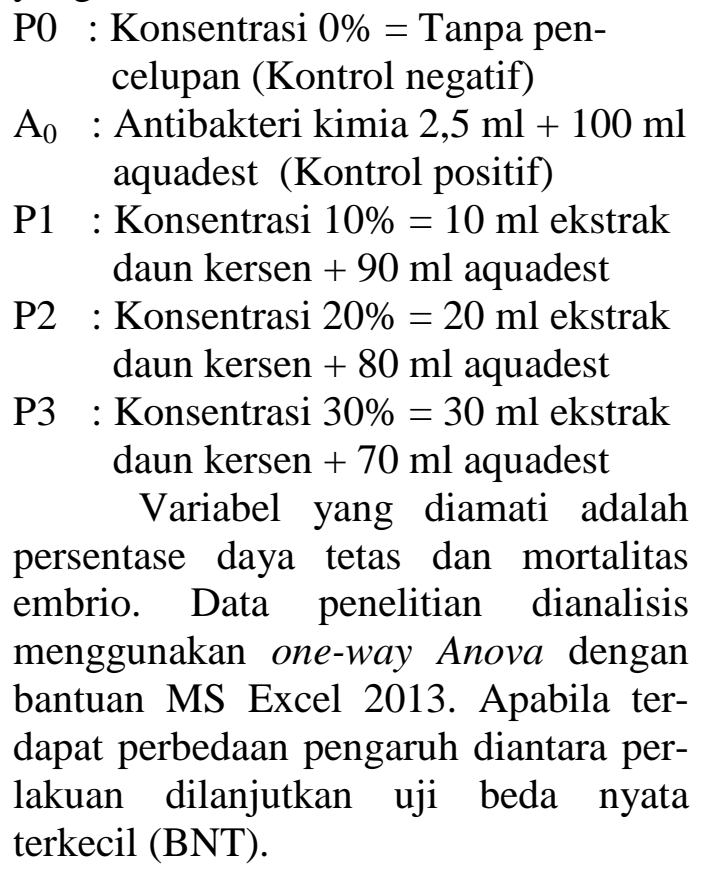

\section{HASIL DAN PEMBAHASAN}

\section{Daya tetas}

Hasil penelitian daya telur tetas itik dengan ekstrak daun kersen pada beberapa proporsi berbeda terhadap daya tetas disajikan pada Gambar 1.

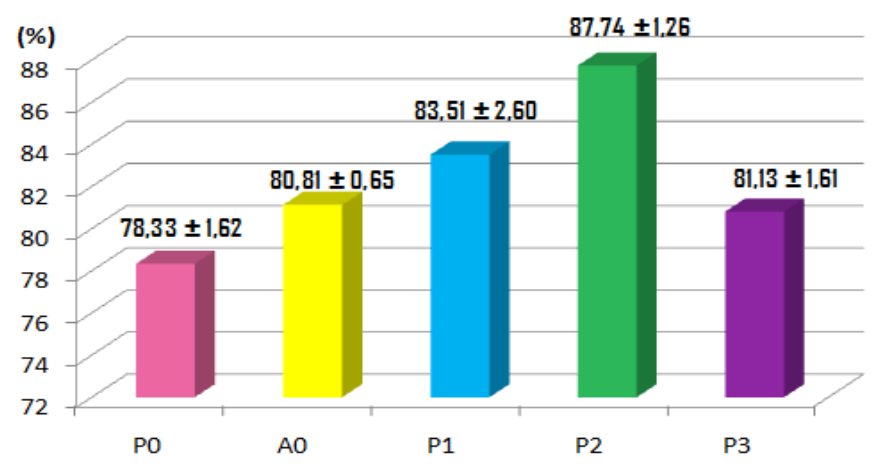

Gambar 1. Grafik daya tetas setelah diberi perlakuan 
Pengaruh pemberian ekstrak daun kersen dalam proses pencelupan telur tetas yang optimal adalah pada konsentrasi 20\% karena mampu meningkatkan daya tetas sebesar 12,01\%. Hasil ini menunjukkan perbedaan yang sangat nyata $(\mathrm{P}<0,01)$. Konsentrasi tertinggi (30\%) memberikan hasil terendah terhadap daya tetas. Hal ini terjadi karena ekstrak yang digunakan untuk pencelupan memiliki konsentrasi yang terlalu pekat sehingga akan menutup pori-pori telur yang menyebabkan kebutuhan oksigen embrio tidak tercukupi. Peningkatan persentase daya tetas telur disebabkan karena zat aktif dalam ekstrak daun kersen mampu menghambat pertumbuhan bakteri merugikan pada telur tetas. Zat antibakteri seperti tannin dan flavonoid berperan dalam peningkatan daya tetas telur.

Tannin merupakan polifenol yang larut dalam air dan banyak dimanfaatkan terutama untuk proses penyamakan kulit. Mekanisme antibakteri tannin antara lain menghambat enzim ektraseluler mikroba, mengambil alih substrat yang dibutuhkan pada pertumbuhan mikroba, atau bekerja langsung pada metabolisme dengan cara menghambat proses oksidasi, sehingga keluarnya air dan gas-gas dalam telur dapat dicegah (Nurwantoro dan Resmisari, 2004).

Adanya bahan-bahan aktif berupa tanin, saponin dan flavonoid yang terkandung sebagai antibakteri pada daun kersen (Muntingia calabura L.) dengan pelarut etanol berperan utama dalam menghambat pertumbuhan maupun membunuh bakteri Streptococcus agalactiae. Sasaran utama kandungan antibakteri dalam ekstrak etanol daun kersen adalah dinding sel.

\section{Mortalitas embrio}

Data hasil penelitian dengan ekstrak daun kersen pada beberapa proporsi berbeda terhadap mortalitas embrio ditampilkan dalam bentuk diagram batang pada Gambar 2.

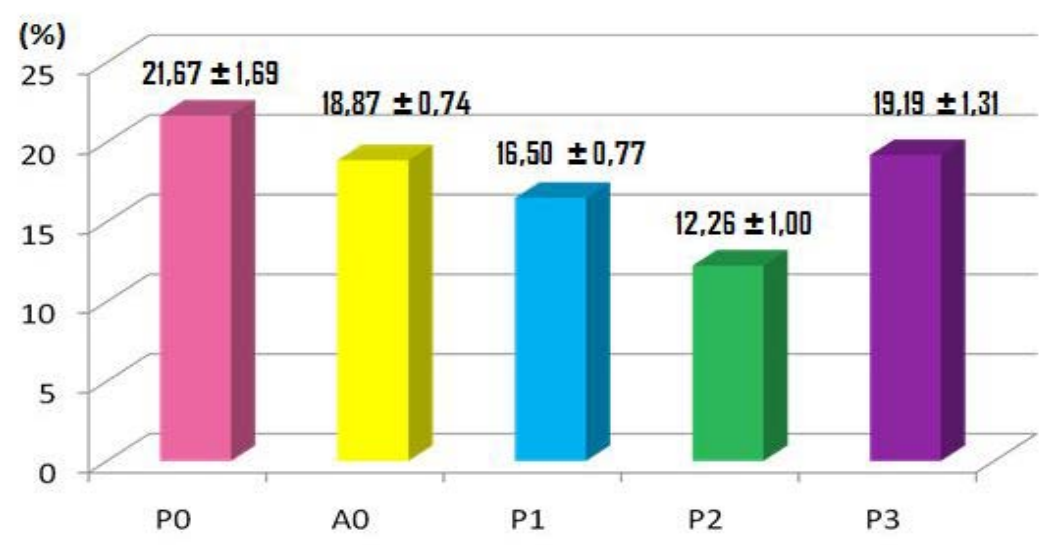

Gambar 2. Mortalitas telur itik dengan pemberian ekstrak daun kersen

Pengaruh pemberian ekstrak daun kersen dalam proses pencelupan telur tetas yang optimal adalah pada konsentrasi $20 \%$ yaitu mampu menurunkan mortalitas embrio sebesar 43,42\%. Hasil ini menunjukkan perbedaan yang sangat nyata $(\mathrm{P}<0,01)$. Tingkat kematian embrio terbesar dihasilkan dari perlakuan tanpa penambahan ekstrak daun kersen (21,67\%). 
Telur yang tidak mendapatkan perlakuan sanitasi pencelupan menggunakan infusa daun kersen tidak memiliki zat antimikroba yang dapat menghambat mikroorganisme. Oleh karena itu mikroorganisme didalam telur lebih mudah berkembang hingga menyebabkan kematian embrio.

Telur itik yang ditetaskan harus bersih dari berbagai kotoran yang melekat pada kerabang telur agar tidak mudah terkontaminasi oleh bakteri yang masuk melalui pori-pori pada kerabang telur yang bisa menyebabkan kematian embrio. Kerusakan telur tetas umumnya terjadi beberapa jam setelah ditelurkan, karena perubahan suhu telur dari suhu tubuh $\left(37^{\circ} \mathrm{C}\right)$ ke suhu kamar yang lebih rendah sehingga terjadi penyusutan isi telur.

Bakteri dengan mudah dapat masuk melalui pori-pori telur dan ketika sudah berada didalam telur sulit sekali untuk dibunuh tanpa membunuh embrio. Bakteri yang diinkubasi bersama-sama dengan telur dapat membunuh embrio itik apabila mencapai konsentrasi yang tinggi (Setioko, 1998).

Perkembangan embrio selama penetasan juga dipengaruhi oleh beberapa faktor salah satunya adalah kejadian meledak (explode). Kejadian explode pada penelitian ini terjadi sebanyak 10 kali. Telur yang mengalami explode pada perlakuan kontrol sebanyak 1 butir dan 10 butir pada konsentrasi 30\%. Hal ini terjadi dikarenakan ekstrak daun kersen yang terlalu pekat menutupi pori-pori telur sehingga embrio banyak yang mati (dead embrio).

Kerabang telur merupakan salah satu struktur telur. Pada kerabang telur terdapat pori-pori yang berfungsi untuk pertukaran gas $\mathrm{O} 2$ dan $\mathrm{CO} 2$ atau digunakan sebagai jalan embrio untuk bernafas. Dewanti, dkk (2009) menjelaskan bahwa fungsi kerabang telur selain untuk mempertahankan bentuk telur dan melindungi telur dari pengaruh lingkungan luar juga digunakan untuk pertukaran oksigen dan karbondioksida.

Oksigen diperlukan embrio selama penetasan, sedangkan karbondioksida dikeluarkan sebagai hasil proses pernafasan embrio. Apabila ekstrak daun sirih yang digunakan sebagai bahan desinfeksi telur tetas memiliki konsentrasi 30\%, maka akan mengakibatkan tingkat mortalitas embrio menjadi lebih tinggi, terutama pada saat umur telur memasuki hari ke-21 sampai hari ke-26 atau pada 7 sampai 2 hari menjelang telur menetas, karena hari-hari tersebut merupakan masa-masa kritis untuk embrio.

\section{KESIMPULAN}

Perlakuan terbaik yaitu dengan penambahan 20\% ekstrak daun kersen yang mampu meningkatkan daya tetas telur sebesar $12,01 \%$ dan mampu menurunkan mortalitas embrio sebesar $43,42 \%$.

\section{UCAPAN TERIMAKASIH}

Penulis mengucapkan terima kasih yang sebesar-besarnya kepada RISTEKDIKTI yang telah mendanai secara penuh penelitian ini dan Bapak Arifin yang telah membantu meminjamkan mesin tetas dan kandang untuk penelitian.

\section{DAFTAR PUSTAKA}

Anderson, S. 2012. Effect of storage temperature on antimicrobial properties of chicken egg white against Salmonella typhimurium and Staphylococcus aureus at various storage condition of liquid egg. $10^{\text {th }}$ Annual TAMUS Pathways Student Research. 
Dewanti, R., Yuhan, dan Sudiyono. 2009. Pengaruh bobot dan frekuensi pemutaran telur terhadap fertilitas, daya tetas, dan bobot tetas itik lokal. Buletin Peternakan. 38 (1): 16-20.

Direktorat Jenderal Peternakan. 2010. Statistik peternakan dan kesehatan hewan. Direktorat Jendral Bina Produksi Peternakan, CV. Karya Cemerlang, Departemen Pertanian RI. Jakarta.

Kurniawan, I., Sarwiyono., Surjowardojo, P. 2013. Pengaruh Teat dipping menggunakan dekok daun kersen (Muntingia calabura l.) terhadap tingkat kejadian mastitis. Jurnal Ilmu-Ilmu Peternakan. 23(3): 27-31.

Nandhra, I. P., Sudjarwo, E., dan Hamiyanti, A. A. 2012. Pengaruh penggunaan ekstrak daun sirih (Piper betle linn.) pada pencelupan telur tetas itik mojosari terhadap daya tetas dan mortalitas embrio. JIIP. Vol 25 (1): 16-23.

Nurwantoro, Y. dan B., Resmisari. 2004. Pengaruh perendaman jus daun sirih (Piper Betle LINN) terhadap jumlah bakteri pada telur itik. Journal Indonesia Tropic Animal Agriculture. Vol 3: 156-160.
Prasetyanti, D. R., Budiarti, C dan Harjanti, D. W. 2016. Efektifitas daun kersen (Muntinga calabura L.) dalam menurunkan jumlah bakteri dalam susu dan peradangan pada ambing sapi perah. Jurnal Ilmu-Ilmu Peternakan. Vol 19(1): 1-16.

Setioko, A. R. 1998. Penetasan telur itik di Indonesia. Wartazoa.7 (2) : 40- 46.

Soeripto dan Poeloengan, M. 1991. Isolasi bakteri dari embrio ayam broiler yang tidak menetas dan sensitivitasnya terhadap beberapa antibiotik. Balai Penelitian Veteriner. Bogor.

Yudhistira, F. A., Murwani, S., Trisunuwati, P. 2012. Potensi antimikroba ekstrak air daun kelor (Moringa oleifera) terhadap Salmonella enteritidis (sp-1-pkh) secara in vitro. Program Kedokteran Hewan. Universitas Brawijaya, Malang.

Zamzamy, S. P., Sudjarwo, E., Hamiyanti, A. A. 2015. Pengaruh penggunaan ekstrak daun beluntas (Pluchea indica less.) pada pencelupan telur tetas itik Mojosari terhadap daya tetas dan mortalitas embrio. Fakultas Peternakan. Universitas Brawijaya, Malang. 